\title{
ISLAMIC PARTIES AND THE POLITICS OF CONSTITUTIONALISM IN INDONESIA'
}

\author{
Mukrimin \\ IAIN Sultan Amai, Gorontalo - Indonesia
}

\begin{abstract}
This article examines the relationship between religion and the state in Indonesia by exploring how Islam is used by political parties to shape the politics. The study shows that Islamic politics is a complementary in both nationhood and statehood in Indonesia. From the early days of the new-born nation-state, Muslims in Indonesia had played significant role in shaping the nation; nonetheless, they have never dominated the political power. Fragmentation among Muslims themselves and internal political parties is among the reason why religious (Islamic) parties failed in bringing religious identity to the state arena. Political subordination-inclusion-ignoranceconfrontation is the circular game that features Islamic politics in Indonesia. The debatable issue on shari'ah law, which is frequently used by Islamic parties, always becomes the core problem of the relation between Islam and the state. Even though Islam has played an important role in colouring the Indonesian politics, its existence remains complementary.
\end{abstract}

Keywords: Islamic parties, constitution, shari'ah.

\section{Introduction}

The discussion of Islam in Indonesia had been marginalized in the global arena in the beginning of twentieth century. Although Indonesia is the most populous Muslim country, it is sometimes perceived to play

\footnotetext{
${ }^{1}$ The earlier version of this paper was presented at The $12^{\text {th }}$ Annual International Conference on Islamic Studies (AICIS), held by the Ministry of Religious Affairs and the State Institute of Islamic Studies (IAIN) Sunan Ampel, Surabaya, 5-8 November 2012.
} 
less significant role in shaping the world Islam. Looking at Islam as a 'political power' frequently refers to its role in its center, i.e. the Middle East. The reason could be; first, Muslims in Indonesia are perceived 'less Islamic' compared to those in the Middle East; second, Islam as politics has never been a single political majority power in the country. Only very recently, after some tragedies such as Bali bombings and regional link of Jamaah Islamiyah, and the current emergence of very view Islamic parties, does the discussion on Islam in Indonesia invite wider concerns.

As reflected strongly by Wahab Hasbullah ${ }^{2}$ in the early days of a new born state, it is difficult to deny that Islam could not be separated from Indonesian politics. Despite the fact that Indonesia is not an Islamic state, it is neither a secular one. We may call it a religion-based state. Pancasila-five principles ${ }^{3}$, the foundation of the state has so far been established. "Belief in One God", the first principle, is perceived as addressing and accommodating religious matters. It is believed that Pancasila has a fundamental element in the separation between religion and the state. As it has been noted that Pancasila does not acknowledge the word "secularism", or a firm separation between religion and politics, or insistence that religion has no place in the state. Constitutionally, furthermore, the Article no. 29 (1) of the 1945 constitution states that "The state shall be based upon the belief in the One and Only God". Although to some extent it limits acknowledgement to six officially recognized religions (Buddhism, Catholic, Hinduism, Islam, Protestantism, and recently Confucianism), the Article 29 (2) provides that "The state guarantees all persons the freedom of worship, each according to his/her own religion or belief". A scholar stresses that to maintain a commitment to an egalitarian and pluralistic society, Pancasila has to abstain from favoring a particular religion as privileged by the state. ${ }^{4}$

2 "If someone is able to separate sugar from its sweetness, he will be able to separate Islam from politics". See Adam Schwarz, A Nation in Waiting: Indonesia in the 1990s (Colorado: Westview Press, 1994), p. 162.

${ }^{3}$ Founded in 1945: belief in one supreme God, humanitarianism, nationalism expressed in the unity of Indonesia, consultative democracy, and social justice.

${ }^{4}$ A. An-Naim, Islam and the Secular State: Negotiating the Future of Shari' ah (Massachusetts: Harvard University Press, 2008), p. 262. See also J. Fox, A World Survey of Religion and the State (Cambridge: Cambridge University Press, 2008), p. 202. 
In this paper, I argue that Islamic politics is a complementary in both nationhood and statehood in Indonesia. Since Independence, Muslim play significant role in shaping the nation; yet, they have never dominated the political power. It is mainly because fragmentation of Muslim leaders and Indonesians, arguably, tend to be reluctant in bringing religious identity to the state arena. Greg Fealy points out that the internal disagreement and rivalries has become the reason why Islam has not enjoyed greater power as an autonomous legitimate power. ${ }^{5}$ Additionally, political Islam has long been marginalized and distrusted by the state, i.e. the Soekarno and the Soeharto regimes to run the country. Marginalization of Islam sometimes claimed by Islamic parties coin the voices of Muslim within the state. However, by accommodating religious matters; such as Ministry of Religious affairs, addressing Islamic economic systems e.g. Bank Syari'a, Islamic Jurisprudence; within the state is intelligently set up by the state actors to reduce potential power of political Islam. Thus, the internal conflict and distrust of the state become the reason why Islam has never dominated the major political power.

The essay begins looking at short history of Islam followed by the characteristic of the religion in Indonesia. Next, I look briefly at the debate on the implementation of shari'ah law. This matter becomes relevant because the distinction of the state and the religion function is mainly about the shari'ah law. At this point, I employ the work of Andrea Teti and Andrea Mura on 'Islamism'. Teti and Mura point out that "Islamism is a set of political and social movements aiming to 'bring Islam back' into politics and society"'. Furthermore, the term 'Islamism' or 'Islamist' groups might be alien in the Muslim world; so, it is important to look at Islam either as purely a religion or a politicsIslam politics. Woodward defines 'Islamist' as "those parties which advocate implementation of shari'ah through either legislation or persuasion"». Not less important term is the call for 'Islamic

\footnotetext{
5 Greg Fealy, "Limits of Indonesian Political Islam," in S. Akbarsadeh and A. Saeed (eds), Islam and Political Legitimacy (London and New York: RoutledgeCurzon, 2003), p. 158.

6 Teti and Mura, "Islam and Islamism," in J. Hayness (ed.), Routledge Handbook of Religion and Politics (London and New York: Routledge, 2008).

${ }^{7}$ Ibid., p. 102.

${ }^{8}$ Mark Woodward, "Indonesia's Religious Political Parties: Democratic Consolidation and Security in Post-New Order Indonesia," Asian Survey, vol. 4, no. 1 (2008), p. 51.
} 
revivalism' over the past decades from within the Muslim world perceiving Islam to have fallen behind major world's civilization also critical to analyze. Thus, understanding both perspectives, Islamism and Islamic revivalism, is useful in studying Islam in Indonesia.

In the next session I will discuss the role of political parties, particularly Islamic parties, in shaping Indonesian politics. In this regard, I apply the term 'politicizing religion' or 'religion politicized' to refer to the use of religion for political purposes. In this regard, the socalled "political Islam" is attributable on how religion politicized. A prominent young Indonesian scholar defines political Islam as any "efforts that promote Muslim aspirations and carry an Islamic agenda into laws and government policy through electoral process and representative (legislative) institution". As in an Indonesia case, some religious parties have very often used religious attributes; such as text, organization, to achieve their own longer term agenda or for short term purposes, e.g. to gain vote in election. The question is how religious parties use religious matters in the politics? And a conclusion will be drawn in the end of this paper.

\section{Islam In Indonesia}

\section{Brief History}

How Islam spread and who brought the religion in the archipelago is critical questions. Importantly, how the religion becomes the majority in a nation which is initially founded on different widespread kingdoms in just less than a century. ${ }^{10}$ To answer these questions scholars have different historical point of views. A Duct scholar, Snouck Hurgronje, claimed that Islam brought by middlemen in trade between the Middle east and Nusantara ${ }^{11}$ and the Malay world. While doing business they also propagated Islam into communities who had different beliefs such Hinduism, Buddhism, and indigenous belief.

\footnotetext{
9 A. Baswedan, "Political Islam in Indonesia: Present and Future Trajectory," Asian Survey, vol. 44, issue 5 (2004), p. 670.

${ }^{10}$ It has been noted that under-25 generation had made up more than two hundred population strikingly in part of the great deal of Islamization of Indonesia, R. Wright, "Islam's New Face Visible in a Changing Indonesia," Online Los Angeles Times, Wednesday, December 27, 2000.

${ }^{11}$ Nusantara literally means archipelago, a name used by the Western colonial such as Portuguese, Duct, and British to refer to archipelagos along Sumatra, Java, Bali, Sulawesi, and Moluccas.
} 
These middlemen followed by the Arabs called Syarif or Sayyid ${ }^{12}$, to complete the spreading of Islam either as "priests", "priest-princes" or Sultans ${ }^{13}$. They were believed mostly as the descendants of the Prophet Muhammad. However, Azyumardi Azra mentions that in Indonesian historians believe that the religion began to widespread directly from Arabia in the first century A.H./seventh century C.E. This theory is based on the style of gravestones at Pasai, North Sumatra especially one dated 27 September 1428, which is similar to the grave of Maulana Malik Ibrahim (d. 1419) in Gresik, East Java. ${ }^{14}$

In the next expansion, Islam became a new belief in the Nusantara. Benedict Anderson noted that the religion widespread through trading not conquest. Rather than revolutionary, it was assimilative penetration. Anderson illustrates the dissemination by arguing that:

... Islam came to the archipelago on the heels not of conquest but of trade. It was first brought by traders and has never lost the marks of its provenance, developing its strongest hold in the immediate, commercial rather than the upper, official or lower, peasant strata. After an initial period of zealotry, the devout Islamic groups were more or less absorbed into the patrimonial state. ${ }^{15}$

It could be true to accept Anderson's theory to attribute the penetration in the early days especially in Javanese kingdoms such as Mataram and Kediri. Yet, the other penetration, in fact, was through war and conquest. Once Islam had been 'officially' embraced by local kings, the local kingdoms sometimes justified Islam to conquer their neighboring 'states' as represented by desperate story of local wars in the eastern region of Indonesia. For example, the well-noted history of Sultan Hasanuddin in Gowa, propagated Islam trough war in its neighbors by attacking Bone, Butan, and until the Moluccas

\footnotetext{
12 Syarif and Sayyid still used by Arabs descendents in some parts of Indonesia, e.g. in Ampel in East Java and in Mandar in the western Sulawesi Pennisula.

13 Sultan also exists in Jogyakarta, Central Java, Pekanbaru Sumatra, Ternate in Moluccas and Pasir in Kalimantan. These mainly occur in former Islamic kingdoms, where local people keep their cultural but not in political term.

14 Azyumardi Azra, Islam in the Indonesian World: An Account of Institutional Formation (Jakarta: Mizan, 2006), p. 11.

15 Benedict Anderson, Language of Power, Exploring Political Cultures in Indonesia (Ithaca and London: Cornell University Press, 1990), p. 68.
} 
archipelagoes. ${ }^{16}$ However, this focus of this paper does not cover the history of penetration of Islam in Indonesia.

Along the historical journey of Indonesia as a nation-state, Islam also grew remarkably. During the Duct and Japanese colonialism, Muslims and their leaders had taken leading role in struggling for independence. Many well-known heroes were ulama (Muslim scholars) who not only thought and led communities in spiritual or religious matters, but also became troop leaders against colonialism. Religious organizations such as Muhammadiyah (founded in 1912), Persis (1920), and Nahdatul Ulama (1926) were the main pockets for fighters against the Duct and Japanese occupation. In short, both Muslims and Islamic organizations have a prominent role in founding Indonesia. With the emergence of Muhammadiyah, Persis and NU, the interpretation of Islam also differed in the so-called "modernist" and "traditionalist" mainstream groups.

According to Burhanuddin, for modernist groups, such as Muhammadiyah and Persis, to comprehend and implement Islam, they follow the salaf method which is to prioritize on the Islamic texts (the Qur'an and Hadits). Thoughts of Ibnu Taimiyah are understood in its literal sense in its theological and ritual aspects. Another important characteristic of these groups tend to be puritan in religious model and rejects cultural factors in religious practices. Literalistic and rationalistic are typical of Muhammadiyah and Persis. As for traditionalist group mainly referred to NU, firmly maintained traditions established by the ulamas in the early period of Islam. The tradition is intended to bridge the Muslim community and Islamic texts. Thus, the distinction of modernist and traditionalist groups lay not only in their views of religion, but also orientation on culture. ${ }^{17}$

There were several elements underlying the contrasting political behavior of NU and Masyumi. First, both parties tended to see themselves as direct competitors for Muslim constituency and both vied for control of the Department of Religious Affairs with its lucrative patronage opportunities and capacity to influence Islamic

${ }^{16}$ For further notes on the war penetration, see for example, Barbara Andaya, The Heritage of Aru Palakka: A History of South Sulawesi in the Seventeenth Century (The Hague: Nijhoff, 1981).

${ }^{17}$ Burhanuddin, "Mainstream Islam in Indonesia," in R. Sukma and C. Joewono (eds), Islamic Thought and Movements in Contemporary Indonesia (Jakarta: Centre for Strategic and International Studies, 2007), pp. 29-31. 
activities at the grassroots level. Finally, NU tended to adopt a more pragmatic and accommodative approach to politics than Masyumi did. NU used politics as a means of securing or protecting its sectional interests, particularly insofar as access to government patronage and the religious bureaucracy were concerned. In pursuing these interests, flexibility, moderation and a capacity for compromise became defining feature of NU's behavior. The Masyumi, by contrast, emphasized resoluteness and consistency in their approach to politics. They were reluctant to compromise on core matters of policy and frequently quoted passages from the Qur'an and hadith enjoining steadfastness and commitment to what is deemed right. In practical politics, these differences inclined NU and Masyumi towards alliances with nonIslamic parties rather than each other. NU was drawn to the Indonesian Nationalist Party (PNI), with its populist, Java-centric orientation; Masyumi found co-operation with the technocratic Socialist Party (PSI) and outer island-based Christian parties. Only on overtly Islamic issues such as the Jakarta Charter did NU and Masyumi co-operate closely. ${ }^{18}$

When Indonesia became a new nation-state, Islam remained as the main belief. It is not clear how Islam suddenly became the majority of religion in a period less than one century. However, the way Indonesian Muslims interpret and understand the religion has been different. The difference is based on the cultural background which is so diverse in Indonesia. In the so-called aliran (literally means 'stream'), the American anthropologist, Clifford Geertz classified the streams within Islam itself into santri, abangan, and abangan. Geertz defines aliran as "comprehensive patterns of social integration". ${ }^{19}$ Doogue and Kirkwood explains this category ${ }^{20}$ :

Santri Muslims, literally means Muslim students, i.e. Muslims, who devout and orthodox in their practice of Islam. Originally this term referred to Muslims who were educated in pesantren, but it now includes all orthodox

\footnotetext{
${ }^{18}$ Fealy, "Limits of Indonesian Political Islam,” pp. 158-9.

${ }^{19}$ Clifford Geertz, "The Javanese Village," in G. W. Skinner (ed.), Local, Ethnic, and National Loyalties in Village Indonesia (Ithaca: Cornell University Press, 1957), p. 57.

${ }^{20}$ Doogue and Kirkwood, Tomorrow's Islam: Uniting Age-Old Beliefs and a Modern World (Sydney: ABC Books, 2005), p. 274.
} 
believers who may not necessarily have a pesantren background;

Abangan Muslims, who combine elements of the prior indigenous, animist, Buddhist and Hindu beliefs with Islam, and they tend to be more nominal and less practicing as Muslims;

Priyayi Muslims, who belong to the Javanese aristocracy and combine abangan beliefs with Javanese courtly culture. Since the global resurgence of Islam in 1970s and 1980s, many abangan and priyayi believers have become santri, and there has been a so-called 'santri-fication' of Islam.

Arguably, this category might be less relevant in today's sociocultural Indonesian Muslims; yet, we look at the pattern of political preference of Muslims in the last two elections, 2004 and 2009, Geertz's category can be traced. It is particularly in within Islamic parties. Even, it is argued that despite the two current elections (2004 and 2009) show the win of nationalist-secular parties is tangible; traditional Muslim voters remain choose the parties based on this category, e. g. the votes for PPP, PKB and PAN are mainly from santri Muslim, as I will discuss this in the next part of this paper.

It is important to note that Islam in Indonesia is typically pluralistic. Plural Islam here means the interpretation of Islam has diverse for many Muslims, i.e., there has been no single concept of how religion deals with the nation-state, for example. The vast majority are Sunni and Shafi'i school of thought. The mainstream of those Sunni-based thought belongs to Nahdathul Ulama and Muhammadiyah. There is a very view of marginal Shii. Not less important is the fact that the existence of indigenous beliefs who incorporate animism and Islam or other major recognized religions e.g. Hinduism and Buddhism. Those indigenous groups, who were sometimes ignored and enforced to any 'alien' religions during the Soeharto regime, now claim their rights to exist before the state.

\section{Sharia Law}

The debate of the position of religion, Islam precisely, in the state has been major subject in the history of Indonesia's politics and constitution. It is mainly the question on whether the shari'ah law is 
recognized in the constitution. ${ }^{21}$ It is particularly surrounded on the socalled Jakarta Charter (Piagam Jakarta), an agreement on 22 June 1945 among the founding fathers such as Soekarno, Muhammad Hatta, AA Maramis, Abikusno Tjoksujoso, Abdulkahar Muzakkir, Agus Salim, Ahmad Soebardjo, Wahid Hasyim, and Muhammad Yamin. The charter turned out to be the 1945 Constitution. Yet, the un-ending bitter debate until nowadays centers around the seven-word clause "... dengan kewajiban menjalankan syariat Islam bagi pemeluk-pemeluknya" $[\ldots$ with the obligation for adherents of Islam to practice Islamic law]. ${ }^{22}$

Interpretation and implication of the charter was vague, according to Greg Fealy. For minimalist group, the obligation to follow shari'ah law set individual Muslims, not the state. The maximalists insist that to ensure adherents of Islam commitment to the shari'ah was the state's function and the constitutional basis for broad legislation would be provided through the charter. Fealy, further, notes that even if most Muslim leaders advocate the inclusion of the clause within the constitution perceived by nationalist and non-Muslims as an effort to create Indonesia an Islamic state, it would not have had this effect. Even, the charter was intended "as an adjunct to Pancasila, not replacement"; the proposal for Islam to be the official state religion never been proposed. ${ }^{23}$

In Indonesia, the term "shari'ah" is commonly understood differently into two meanings. An-Naim illustrates ${ }^{24}$ :

Shari'ah with a capital "S" is used to refer to the totality of God's detailed guidance for humanity. This vision of Shari'ah is believed to be eternal and universal, but it is to be derived from the totality of God's signs (ayat), which are conveyed in the material world, as well as in the Qur'an.

Shari'ah with a small "s", which is fiqh, is the product of the human law-law making process, or ijtihad (juridical reasoning by Islamic scholars according to the traditional methodology of Islamic jurisprudence. However, strongly believed to be

\footnotetext{
${ }^{21}$ Baswedan, "Political Islam in Indonesia," p. 669.

22 For details of the constitution see Lili Romli, Islam Yes, Partai Islam Yes (Yogyakarta: Pustaka Pelajar, 2006), pp. 265-6.

${ }^{23}$ Fealy, Limits of Indonesian Political Islam, p. 155.

${ }^{24}$ An-Naim, Islam and the Secular State, p. 245.
} 
valid and binding, the product of this process is always merely speculative conjecture and necessarily temporary and transient. Although fiqh purports to regulate human behavior, there is always flexibility and freedom for each human being to choose among a range of options without fear of committing an offense or sin that warrants punishment.

\section{Politicizing Islam: Political Parties}

One of the crucial questions in relation to the role Islam as well as other religions have played in national politics are, among others, how religious parties use religion matters in the politics? What are the roles of Islamic parties in Indonesia?

As has been mentioned above, I use the term 'politicizing religion' or 'religion politicized' to refer to the use of religion for political purposes. In this section, I attempt to assess how religious matters used to negotiate the power with the state.

Anderson has suggested that by assessing the major socio-political roles of religion in the Southeast Asian nations, we might frequently express surprise that "religion has always failed politically". It is true that nowhere in the region, with partial exception of Indonesia, have religious leaders become Prime Ministers or heads of state. Indonesia herself is a marginal case, since the Muslim leaders Muhammad Natsir and Sukiman each survived as prime ministers for only a few months. However, Anderson further stated:

"...religion has been a very significant political factor, while
religious leaders and movements have been great political
failures-only makes sense if one believes that religion is
subsumed under politics, and only if one assumes that
religious people in politics see politics in the way that
'secular' people do. What I am suggesting is simply that
from the religious perspective what looks like major political
failure may be quite inconsequential, and that 'failure' in, say,
Jakarta, may not mean failure among millions of ordinary
Indonesians." 25

\footnotetext{
${ }^{25}$ B. Anderson, "'Religion and Politics in Indonesia since Independence," in Benedict R.O.G Anderson et al, Religion and Social Ethos in Indonesia (Victoria: The AustraliaIndonesia Association and the Centre of Southeast Asian Studies, Monash University, 1975), p. 22.
} 
It is true, Anderson's suggestion then proved again when the prominent Muslim leader, Abdurrahman Wahid, had been toppled down and had less than one period of administration in 1999-2001. Being a long time decidedly secular state, a remarkable growing Islamic identity, such as new political parties, Islamic schools, civic groups, Islam media, has redefined Indonesia, according Wright. It is believed that 75 percent of Indonesian Muslims wished to play important role in society and government policy, and about 54 percent of public yearned for religious leaders to get involve vigorously in the politics. ${ }^{26}$

\section{After Independence until the End of the New Order Period}

Acknowledged by the Soekarno regime as the mainstream of Muslim's socio-political representation, NU and Muhammadiyah became stronger. However, as Fealy argues that lack of solidarity and conflict between these organizations became a main element in the political dynamic from the late 1950s, when Soekarno and the army were approaching Indonesia towards the authoritarian Guided Democracy. Masyumi was firmly opposed to toppling down of parliamentary democracy, arguing that it was not only violate the community's democratic rights but also contrary to the Islamic principle that supported consultation (musyawarab) and deliberation (mufakat) between the government and people. By contrast, NU halfheartedly agreed to Guided Democracy, fearing that its own interest as well as those of the broader Muslim community would be endangered if it rejected to involve. It is believed that the agreement and involvement of NU was important to approach Soekarno's Guided Democracy. In the further step, Soekarno exposed his new regime as mixing the diversity of Indonesian politics. Then, the president Soekarno mad up the acronym Nasakom (i.e. Nasinalis-AgamaKomunis or Nationalist-Religion-Communist) to portray the supposed combination of these different elements. ${ }^{27}$ Perhaps, it is the first idea to unite between communism and religion in the world.

It is not surprising, as a result of Masyumi disagreement, the Soekarno regime banned Masyumi in 1960. In 1962 senior Masyumi leaders were arrested and remained under arrest until 1967. The parliament restricted by reducing Islamic parties into just 25 percent,

\footnotetext{
${ }^{26}$ Wright, Los Angeles Times, Wednesday, December 27, 2000.

${ }^{27}$ Fealy, "Limits of Indonesian Political Islam," p. 159.
} 
down to 45 percent in the 1955 democratically elected parliament. The regime also decreased NU's involvement over the direction of government. In this case, Fealy suggests that marginalization of Islam politics was the consequence of the lack solidarity of Islamic groups in the Soekarno regime. ${ }^{28}$

In 1966 the New Order emerged. Led by general Soeharto, the regime isolated and detained Soekarno. The Soeharto regime, according to Fealy, placed Islam as a political force into suspicious and distrusted Muslims leaders. Despite it allowed the founding of new Islamic party, Parmusi (the Indonesian Muslim Party) in 1967, it did not permit to rehabilitate Masyumi. Similar with Soekarno regime, the New Order and particularly Soeharto himself believed that Islamic political parties were potential power challengers that could undermine the secular based state. Accordingly, by domesticating Islamic parties, Muslim elites and proponents of shari'ah law not only failed to make Islamic state, but also they were marginalized and perceived as "minorities" or "outsiders" in the state. They were frequently perceived as anti Pancasila. Again, as it has been suggested that in the early the New Order regime the political Islam was "constitutionally, physically, electorally, bureaucratically, and symbolically defeated." 29

In addition, in the Soeharto regime, Islam had been "politicized", according to Hefner. Suspecting Islam as potential power contender to national politics, the government initiated and enforced all social and political groups, including religious organizations, to use Pancasila as their "sole foundation" (asas tunggal). It was believed that by pushing socio-political organizations under the Pancasila base policy, Muslims considered their organization to have been completely destructed. Party of Unity and Development (PPP), the only Islamic party at that period, for example, bitterly accepted the government's policy. The policy considered similar to the earlier Dutch colonial effort of allowing "Islamic religion but ruthlessly repressing all forms of political Islam". 30

\footnotetext{
${ }^{28}$ Ibid., p. 160.

${ }^{29}$ B. Effendy, Islam and the State in Indonesia (Singapore: Institute of Southeast Asian Studies, 2003), p. 2.

${ }^{30}$ Hefner, Civil Islam, pp. 121-122. Further discussion on this, see Anthony Reid, "Nineteenth Century Pan-Islam in Indonesia and Malaysia," The Journal of Asian Studies, vol. 26, no. 2 (1967), pp. 267-283.
} 
Furthermore, the relation between the state and Islam had been fluctuated. However, as Taba notes a number of accommodative actions by the New Order regime to Muslim, as shown in the table below:

Figure 1: Number of accommodative actions by the New Order regime to Muslim

\begin{tabular}{|c|c|c|c|}
\hline Cases & Year & Initiative & State \& Muslims Response \\
\hline $\begin{array}{l}\text { The demand to } \\
\text { abolish the ban } \\
\text { using Jilbab in } \\
\text { schools }\end{array}$ & $\begin{array}{l}\text { 1980s/ear } \\
\text { ly 1999s }\end{array}$ & Muslims & $\begin{array}{l}\text { the state accommodated the } \\
\text { demand and in } 1991 \text { the ban } \\
\text { was abolished }\end{array}$ \\
\hline $\begin{array}{l}\text { National } \\
\text { Education } \\
\text { Constitution } \\
\text { Draft }\end{array}$ & 1988 & State & $\begin{array}{l}\text { Created strong reaction among } \\
\text { Muslims. However, Muslims' } \\
\text { opposition reduced through } \\
\text { lobbying by Muslim leaders. } \\
\text { The government finally } \\
\text { accommodated Muslims' } \\
\text { demand and all the drafts } \\
\text { which considered against } \\
\text { Islamic values were rejected. } \\
\text { Regulation on education that } \\
\text { not pro Islamic education was } \\
\text { rejected. }\end{array}$ \\
\hline $\begin{array}{l}\text { Draft of } \\
\text { Religious } \\
\text { Jurisprudence }\end{array}$ & 1988 & State & $\begin{array}{l}\text { Muslims responded } \\
\text { enthusiastically because it was } \\
\text { believed giving support for } \\
\text { Muslim interest }\end{array}$ \\
\hline $\begin{array}{l}\text { SDSB } \\
\text { (gambling) }\end{array}$ & $1990 \mathrm{~s}$ & Muslim & $\begin{array}{l}\text { Government accept Muslims } \\
\text { objection and the gambling } \\
\text { was banned }\end{array}$ \\
\hline $\begin{array}{l}\text { YABMP } \\
\text { (Muslim- } \\
\text { Pancasila } \\
\text { Foundation) }\end{array}$ & $\begin{array}{l}1980 \mathrm{~s} \& \\
1990 \mathrm{~s}\end{array}$ & State/president & $\begin{array}{l}\text { Muslims responded positively } \\
\text { to gain fund-support to build } \\
\text { mosques around Indonesia }\end{array}$ \\
\hline $\begin{array}{l}\text { Joint-Degree } \\
\text { between } \\
\text { Ministry of } \\
\text { Home Affairs \& } \\
\text { Religious }\end{array}$ & $1990 \mathrm{~s}$ & State & $\begin{array}{l}\text { Muslims accepted the initiative } \\
\text { of government to arrange the } \\
\text { religious charity (zakat) }\end{array}$ \\
\hline
\end{tabular}




\begin{tabular}{|c|c|c|c|}
\hline Cases & Year & Initiative & State \& Muslims Response \\
\hline \multicolumn{4}{|l|}{ Ministry } \\
\hline Musmalat Bank & $1990 \mathrm{~s}$ & State & $\begin{array}{l}\text { Muslims positively the } \\
\text { establishing of the so-called } \\
\text { Bank Shari'ah Muamalat }\end{array}$ \\
\hline $\begin{array}{l}\text { Muslim Scholars } \\
\text { Association } \\
\text { (ICMI) }\end{array}$ & $1990 \mathrm{~s}$ & $\begin{array}{l}\text { Muslim, then } \\
\text { state took the } \\
\text { initiative }\end{array}$ & $\begin{array}{l}\text { State supported and Muslims } \\
\text { broadly advocated }\end{array}$ \\
\hline Istiqlal Festival & 1990 & $\begin{array}{l}\text { Muslim } \\
\text { (particularly } \\
\text { ICMI }\end{array}$ & $\begin{array}{l}\text { State supported even } \\
\text { sponsored. }\end{array}$ \\
\hline
\end{tabular}

Source: Lili Romli, Islam Yes, Partai Islam Yes (2006), pp. 89-91, adapted Abdul Azis Thaba, Islam dan Negara dalam Politik Orde Baru [Islam and the state in the Politics of the New Order] (1996), pp. 313-5.

Additionally, Effendy classified the New Order regime's accommodation into four kinds: (1) structural; mainly on education, (2) legislative; the National Education Law, religious court, and the compilation of Islamic jurisprudence, reversal of policy on jilbab, religious alms, annulment of lottery, (3) infrastructural; Muslim Pancasila Foundation, "religious project" in Five-Year Development Plan, (4) cultural; adoption of Islamic (Arabic?) idiom into Bahasa Indonesia. ${ }^{31}$ Additionally, in the early years of the New Order, the founding of Majlis Ulama Indonesia (Indonesia's Council of Ulama'sMUI) considered "as a toll to keep politically minded Islamic organizations in check", according Gelling. 32

From socio-political perspective, as Romli has suggested that the founding of the Indonesian Muslim Scholars Association (ICMI) was phenomenal accommodation of Soeharto regime. Led by Habibie, hundreds of Muslim prominent leaders from diverse background were collected to support the New Order interests. Habibie's unique origin was important because he was not from prominent Islamic groups but a Muslim technocrat and bureaucratic based. ${ }^{33} \mathrm{He}$ himself was

\footnotetext{
${ }^{31}$ Effendy, Islam and the State, pp. 151-171.

32 P. Gelling, "Islamic Group Gain Power in Indonesia," online New York Times, October 7, 2008.

${ }^{33}$ Romli, Islam Yes, Partai Islam Yes, pp. 92-96.
} 
sometimes called "super minister" due to a number of essential ministries and departments that he headed, then replaced President Soeharto. The pros-cons of the ICMI founding featured Muslims position, particularly Islamic organization, in the 1990s of New Order. ${ }^{34}$ In short, the so-called "Pancasila Democracy", the Soeharto regime effectively isolated political Islam.

\section{During Reformasi and transition era}

There have been significant changes in Indonesian politics after the post-Soeharto regime in 1998. It included the emergence of a many Islamic parties. During 1998 and 1999, the political parties were mushrooming, including Islamic parties. In this era, as reported that there were about 184 political parties, but 148 of which proposed to establish and yet only 141 among them were approved. And there were only 48 parties joined the general elections. ${ }^{35}$ And 21 out of 42 parties were categorized as Islamic; typically clearly use Islam as their ideological foundation. ${ }^{36}$ Woodward classifies the parties into four main groups ${ }^{37}$ :

Clearly secular parties resisted Arab-like variant of Islam and a more noticeable role of Islam in politics. It appealed to Hindus, Christians and other. Indonesian Democratic PartyStruggle (PDIP) and the Golkar Party were the categories in this group.

Islamic parties led by famous Muslim leaders that focus their segments on Muslim community. PKB and PAN could be classified in this group.

Islamic parties that support a significant position within politics and focus on family law, Bank shari'sh and advocated anti-pornographic and "porno action" law. PKS, PBB, and PPP represented this category.

A small number of Christian parties.

\footnotetext{
${ }^{34}$ Further discussion on ICMI and Islam, see D. Ramage, Politics in Indonesia (London and New York: Routledge, 1995).

${ }^{35}$ Romli, Islam Yes, Partai Islam Yes, p. 107.

${ }^{36}$ Effendi, Islam in Contemporary Indonesian Politics, p. 180.

37 Mark R. Woodward, "Indonesia's Religious Political Parties: Democratic Consolidation and Security in Post-New Order Indonesia," Asian Survey, vol. 4, no. 1 (2008), pp. 48-9.
} 
Woodward also remarks that in 1999 election the secular parties, PDI-P and the Golkar, gained 66.16 in aggregate votes. And the 'grey' parties such as PKB and PAN also came into top ten major parties..$^{38}$ It is noteworthy that the major political parties were reliant heavily on their 'charismatic' or symbolic leaders ${ }^{39}$. For example, Megawati's PDIP, Abdurrahman Wahid's PKB, and Amien Rais' PAN.

Although religious parties are not dominated by Islam, and there are Catholic and Protestant parties as well, the establishment of Islamic parties has opened up a public concern. Motives and motivation of the emergence of so many Islamic parties had been questioned by many intellectuals and political analysts. Political inference and the repercussions for the future of Indonesia politics was also of the concerns. Importantly, the concern of minority groups, like Catholic and Protestants, who were supported by secular groups believed that the rise of so many Islamic parties leaded to anxiety that such religionbased parties might increase "political sectarianism". For minority groups, the rise of Islamic parties could eventually lead to national disintegration. ${ }^{40}$ Concern of the minority groups is not new. Azra states, "It is not secret that for many years Christians have believed that Muslims generally still support the establishment of an Islamic state in Indonesia" 41 . The increase suspicious of non-Muslim groups is understandable because many political parties replaced their ideological foundation from Pancasila to Islam.

However, many Indonesia Muslim figures believe that the emergence of Islamic parties after the fall of Soeharto regime was simply euphoria of era reformasi, which is generally understood by the Muslim elites to mean political freedom and democracy. That was not surprising because many Muslim political leaders were suppressed and marginalized during the New Order regime. Yet, it was commonly believed as counterproductive for the unity and welfare of Indonesian

\footnotetext{
38 Ibid., p. 49.

${ }^{39}$ For the discussion of 'charismatic leader" in Indonesian politics, see B. Anderson, Language and Power, Exploring Political Cultures in Indonesia (Ithaca: Cornel University Press, 1990).

40 Azyumardi Azra, Indonesia, Islam, and Democracy: Dynamics in a Global Context (Jakarta: Solstice and International Centre for Islam and Pluralism, 2006), p. 6.

41 Ibid., p. 28.
} 
Muslim society. 42 In fact, the rise of so many Islamic parties exacerbated the fragmentation of Muslim politics. Again Anderson's thesis on the failure of political Islam in during reformasi era proved to be true. It should be kept in mind, however, that they played critical role in stabilizing Indonesia' peaceful transition to democracy. Even, their participations and contention in peaceful way through the elections were constructive. ${ }^{43}$

Commenting the failure of Islamic parties in the 1999 election, Effendy stresses two aspects should be taken into account. First, the view of religious loyalty will automatically be followed by political endorsement has not occurred. In fact, Islamic parties had no enough acknowledgement of socio-cultural and demographic background of Indonesian voters that always change. Religious issues could not totally be raised to shape political preference, even if the aliran politics still influential. Second, the image of Islamic parties, frequently equated with Islamic state or the issue of the incorporation of the shari ah law into the state constitution, was critical factor as well. ${ }^{44}$ These factors, I believe, are attributable to the unpopularity of Islamic parties in the 2004 and 2009 general elections.

\section{After reformasi and beyond: future prospects}

It is important to note that the discourse of Islamic state or shari'ah law re-emerged after the fall of Soeharto regime. Yet, it was not risen by political parties but Islamic organizations during this period. As Azra has state that in the 2004 election, Islam and Islamic issues "did not become the central and big issues"; rather, most Indonesians "were concerned mostly with issues they face in the real life" such as economic downturn, widespread corruption, law enforcement, and other social ills like drugs and poverty. ${ }^{45}$

In addition, An-Naim points out that generally the debate happened among those proponents who advocate an active role of the state in ensuring the Jakarta Charter. They were including Dewan Dakwah Islamiyab Indonesia (the Indonesian Islamic Preaching Council-

\footnotetext{
42 Ibid., p. 29

43 Abdulbaki, "Democratic in Indonesia: from Transition to Consolidation," Asian Journal of Political Sciences, vol. 16, no. 2 (2008), p. 165.

${ }^{44}$ Effendy, Islam in Contemporary Indonesian Politics, pp. 193-4.

45 Azra, Indonesia, Islam, p. 215.
} 
DDII), Komite Indonesia untuk Solidaritas Dunia Islam (the Indonesian Muslims' World Solidarity-KISDI), Majelis Mujabidin Indonesia (the Indonesian Mujahidin Council-MMI), Front Pembela Islam (the Islam Defender Front-FPI), Laskar Jihad, Hizbut Tabrir Indonesia (HTI), and others. The groups such as Nabdathul Ulama, Muhammadiyah, and such Islamic non-governmental organizations as Paramadina, Jaringan Islam Liberal (Islam-Liberal Network-JIL), and others firmly opposed the idea of formal state's sponsor of shari'ah law. ${ }^{46}$

However, by and large, Indonesian Muslims' commitment to democracy is obvious as shown in general elections over the last decade. In 1999 and 2004 general elections, voter participation was high: 91 percent and 84 percent respectively, and 77 percent for 2004 presidential election. Broad support of Muslim communities for democracy is consistently strong. In 2008, 82 percent of Muslim preferred democracy as the best political system for Indonesia, according to a poll. ${ }^{47}$ This shows that Indonesian's recent political development through democracy has been consolidated.

Furthermore, during this period, a number of significant developments of democratic process are significant. Abdulbaki confirms that constitutional amendments, for example, that guarantee of freedom of expression and association and media as well, are good efforts. Also significantly, the elimination of the possible re-emergence of a new presidential dictatorship has taken place. And political parties are no longer urged to adopt Pancasila as the sole foundation by removing the ideological uniformity on the political party's base. 48

The idea of implementing shari'ah law, particularly through constitutional change in the 2009 election is mainly supported by very view parties in the parliament. It is pretty much similar with the 2004 election. However, the non-formal parties, groups outside parliaments, such as Hizbut Tahrir Indonesia (HTI) and Islamic groups still struggle to be included in the state's power to ensure the shari'ah law. Equally essential, thanks to the implementation of decentralization, the debate

\footnotetext{
46 An-Naim, Islam and the Secular State, p. 231. See also the report of the Jakarta Post, Tuesday, 18 September 2007, available at: http://www.thejakartapost.com/print/152411 [consulted, 8 June 2011].

${ }^{47}$ Greg Fealy, "Indonesia: Pietism and Compromising for Power," in A. Bubalo et al (eds), Zealous Democrat (Lowy Institute, 2008), pp. 55-6.

48 Abdulbaki, "Democratic in Indonesia," pp. 156-8.
} 
of shari'ah law also shifted from national to local issue. From more than four hundred districts/municipalities and 32 provinces, only very view of them have passed any shari'ah-based local regulations. ${ }^{49}$ As Ramage has stated, it was not Islamic parties, but by secular ones, dominating the passing of local shari'ah regulations. The "shari'ahnization" movement in a small number of districts believed undermining Indonesia's pluralism and diversity. ${ }^{50}$ Another example of shari'ah-based issue is the anti-pornography bill that seems less vocal now in the implementation. ${ }^{51}$

In the very recent calculation, Greg Fealy stresses "of the nine general elections held since 1955, Islamic parties have never gained more than 44 percent of vote-that is less than half of the Muslim vote". Even in the 2004 and 2009 elections, they obtained only about 38 percent of the vote. ${ }^{52}$ A similar prediction of an Indonesian prominent historian is rather convinced that Islamic parties will not rise "as a big political force in the elections in 2009" because "reinvigorated Islamic discourse that practically divided the ummah into several clusters of religious orientation" affects the political development. ${ }^{53}$ The table below depicts comparison of the top-list party votes in 2004 and 2009 general elections:

\footnotetext{
${ }^{49} \mathrm{It}$ is arguably debatable that whether the local regulations were genuinely shari'ah or not because as far as I concern the claim for shari'ah regulations, such as the obligation to have the Koran acquisition was not purely shari $\bar{i}^{6}$ h law. Furthermore, the only one province, i.e. Aceh has officially claims as specific region to implement the shari'ah; yet, a number of Acehnese colleagues are convinced that what the Acehnese government claims abouth shari'ah was totally different with the reality. In fact, there is not distinctive difference between Aceh province and the rest of 32 provinces of Indonesia. The Jakarta Post released that 250 shari'ah bylaw have been passed in South Sulawesi, West Java, Banten, West Sumatra, West Kalimantan and Aceh, The Jakarta Post, Tuesday, 18 September 2007, available at: http://www.thejakartapost.com/print/152411 [consulted, 8 June 2011].

${ }^{50}$ Ramage, Indonesia Democracy First, pp. 147-8.

51 Further discussion, see P. Allen, "Challenging Diversity?: Indonesia's AntiPornography Bil,” Asian Studies Review, vol. 31 (2007), pp. 101-115.

52 Fealy, "Islamic lens the wrong way to see Indonesia," online The Jakarta Post, Saturday, 14 March 2009, available at: http://www.thejakartapost.com/print/203203 [consulted, 8 June 2011].

${ }^{53}$ Interview The Jakarta Post with Taufik Abdullah, online The Jakarta Post, Tuesday, 18 September 2007, available at: http://www.thejakartapost.com/print/152411 [consulted, 8 June 2011].
} 
Figure 2: Comparison of the Top-list Party Votes in 2004 and 2009 General Elections

\begin{tabular}{lrrl}
\hline \multicolumn{1}{r}{ Party } & $\mathbf{2 0 0 4} \mathbf{( \% )}$ & $\mathbf{2 0 0 9} \mathbf{( \% )}$ & \multicolumn{1}{c}{ Ideology/Base } \\
\hline Democrat & $7.45 \%$ & $20.36 \%$ & Secular-nationalist \\
PDIP & 18.53 & 14.32 & Secular-nationalist \\
Golkar & $21.58 \%$ & 14.24 & Secular-nationalist \\
PKS & $7.34 \%$ & $8.46 \%$ & Islam \\
PAN & $6.44 \%$ & $6.36 \%$ & Islam \& nationalist \\
PPP & $8.15 \%$ & $5.46 \%$ & Islam \\
PKB & $8.15 \%$ & $5.12 \%$ & Islam \& nationalist \\
Gerindra & n. a. & $4.47 \%$ & Secular-nationalist \\
Hanura & n. a. & $3.52 \%$ & Secular-nationalist \\
PBB & $2.62 \%$ & $1.98 \%$ & Islam \\
\hline
\end{tabular}

Source: Indonesia's Election Commission (KPU), available at http://www.kpu.go.id and adapted by the writer.

The result of the 2009 election raises the anxiety about the emergence of Islamic parties particularly Partai Keadilan Sejabtera (the Prosperous Justice Party-PKS). Employing the Egyptian Islamist Muslim Brotherhood method, this party has been believed as reemerging of Islamist in Indonesia. Although it slightly increases, it is surprising many when the party 'only' achieved more than 8 percent because before the election the PKS's leaders and members strongly believed on their calculation that they would gain 20 percent in this vote. ${ }^{54}$

Again, in general, the Islamic parties will not dominate Indonesia's politics. There are three underlying "classical" factors, according Effendy, why they do not gain significant votes in the 2009 election: first, "the inability of Islamic parties to translate ideological identity into concrete programs". It is because voters believed that Islam has not proven itself as a major in politics. Second, the internal conflict and disunity within Islamic parties is also critical reason they failed. Finally, philosophical shifting "from being ideologically driven in the

54 Online Channel News Asia, "Indonesian voters lose faith in Islamic Parties," available at: http://wwwchannelnewsasia.com/stories/afp_asiapacific/view/420229/$\underline{1 / . h t m l}$ [consulted, 6 April, 2011]. 
1940s and 1950s, to pragmatist now" influence the failure of Islamic parties. ${ }^{55}$

Finally, any attempt to support the consolidating democracy in Indonesia is crucial. Skeptical, even pessimistic, view that Islam is not compatible with democracy should be answered by solving problems that could undermine the democratic values. Indonesia's challenges of democracy, as Azra has suggested, associated with four factors. First, prerequisites of democracy, such as education and economic development, are less developed. Patrimonialism and corruption still rampantly undermine the nation-state development. Second, some Indonesia Muslims tend to believe the nostalgia to unite and merge religion and politics; by translating into formalization of Islam in politics. Third, the lack of democratic culture among political elites and Muslim communities also remains the problem. Lastly, the role of civil society organizations is fragile too. To support democratic consolidation, the pivotal position of Islamic civil society groups has to be advocated. ${ }^{56}$

\section{Conclusion}

The central argument underlying this paper has been, first, political Islam, particularly Islamic (Islamist?) parties, plays significant role in the state of Indonesia. Second, the role of Islamic parties has never been dominating the national politics. The failure of political Islam since independence is due to two main factors: internal conflict among themselves and the state pressure. As Abootalebi and Abdulbaki have suggested that "the relationship between Islam and the state or the role of Islam in political life ranges from subordination of the state to Islam... to political accommodation... to political inclusion of Islam... to toleration... to ignoring Islam... to direct confrontation" in the political landscape of many Muslim countries has also taken place in Indonesia. ${ }^{57}$

Being the largest Muslim country, in terms of population, Indonesia has experienced a relatively short journey to democracy. Since independence in 1945, the country ever adopted the so-called

\footnotetext{
${ }^{55}$ Bachtiar Effendy, "Islamic Parties have long been at an Impasse," on line the Jakarta Post, Friday, 17 April 2009, available at: http://www.thejakrtapost.com/print/207338 [consulted, 1 May 2011].

56 Azra, Indonesia, Islam, pp. 24-25.

57 Abdulbaki, "Democratic in Indonesia," p. 156.
} 
"Guided Democracy" coined by the Soekarno and "Pancasila Democracy" forced by Soeharto. Both regimes had politically isolated and distrusted Islam as the potential political contender. When the New Order dismantled, political landscape created political euphoria marked by mushrooming political parties, particularly Islamic-based ones, that also confusing Muslims. It is understandable then, Indonesian citizen have little experience with real and genuine democracy.

The debatable issue on shari'ah law, which is frequently used by Islamic parties, always becomes the core problem of the relation between Islam and the state. As it has been suggested that Islam and Muslims played pivotal role in shaping Indonesian politics; yet, bitterly enough to say that the involvement of Islam with Indonesia's politics remains complementary factor. Internal conflict and disunity among Islamic parties and the state policy, such as marginalization and distrust, are attributable to losing of the parties. It seems that using Islam in the political world by elites repeatedly fail to dominate the power. In my final remark, I believe that Indonesians themselves tend to prefer national (secular) cohesion by choosing nationalist parties rather than by bringing Islam into pragmatic politics. []

\section{Bibliography}

\section{Books and Articles}

Abdulbaki, L. "Democratization in Indonesia: From Transition to Consolidation." Asian Journal of Political Science, vol. 16, no. 2 (2008): pp. 151-172.

Akbarzadeh, S. and A. Saeed (eds). Islam and Political Legitimacy. London and New York: Routledge Curzon, 2003.

An-Na'im, A. A., Islam and the Secular State: Negotiating the Future of Shari ah. Massachusetts: Harvard University Press, 2008.

Azra, A. Islam in the Indonesian World: An Account of Institutional Formation. Jakarta: Mizan, 2006.

-. Indonesia, Islam, and Democracy: Dynamics in a Global Context. Jakarta: Solstice Publishing, 2006.

Anderson, B. "Religion and Politics in Indonesia since Independence." Benedict R.OG Anderson et. al. Religion and Social Ethos in 
Indonesia. Victoria: The Australia-Indonesia Association and the Centre of Southeast Asian Studies, Monash University.

--------. Language and Power, Exploring Political Cultures in Indonesia. Ithaca: Cornell University Press, 1990.

Baswedan, A. R. "Political Islam in Indonesia, Present and Future Trajectory." Asian Survey, vol. 44, issue 5 (2004): pp. 669-690.

Doogue, G and P. Kirkwood. Tomorrow's Islam: Uniting Age-Old Beliefs and a Modern World. Sydney: ABC Books, 2005.

Effendy, B. Islam and the State in Indonesia. Singapore: Institute of Southeast Asian Studies, 2003.

--------. Islam in Contemporary Indonesia Politics. Jakarta: Ushul Press, 2006.

Fealy, G. "Divided Majority: Limits of Indonesian Political Islam." Akbarzadeh, S. and A. Saeed (eds). Islam and Political Legitimacy. London and New York: RoutledgeCurzon, 2003. -. "Indonesia: Pietism and Compromising for Power." A. Bubalo et. al. (eds). Zealous Democrat: Islamism and Democracy in Egypt, Indonesia and Turkey. Paper 25. New South Wales: Lowy Institute, 2008.

Fox, J. A World Survey of Religion and the State. Cambridge: Cambridge University Press, 2008.

Geertz, C. The Interpretation of Culture, Selected Essays. New York: Basic Books, 1973.

Hefner, R. W. Civil Islam, Muslims and Democratization in Indonesia. New Jersey: Princeton University Press, 2000.

Ramage, D. E. "Indonesia: Democracy First, Good Governance Later." Southeast Asian Affairs, 2007.

Romli, L. Islam Yes, Partai Islam Yes. Jakarta: Pustaka Pelajar, 2006.

Schwarz, Adam. A Nation in Waiting: Indonesia in the 1990s. Colorado: Westview Press, 1994.

Sukma, R. and C. Joewono (eds). Islamic Thought and Movements in Contemporary Indonesia. Jakarta: Center for Strategic and International Studies (CSIS), 2007. 
Mukrimin

Teti, A and A Mura. "Islam and Islamist." J. Haynes (ed.). Routledge Handbook of Religion and Politics. London and New York: Routledge, 2008.

Woodward, M. “Indonesia's Religious Political Parties: Democratic Consolidation and Security in Post-New Order Indonesia." Asian Survey, vol. 4, no. 1 (2008): pp. 41-60. 